\title{
Reviewing carbon spiraling approach to understand organic matter movement and transformation in lotic ecosystems
}

\author{
Revisando a abordagem de espiral do carbono para entender o movimento e \\ transformação da matéria orgânica em ecossistemas lóticos
}

Leonardo Kleba Lisboa $^{1 *}$, Steven Thomas ${ }^{2}$ and Timothy Peter Moulton ${ }^{1}$

\begin{abstract}
${ }^{1}$ Laboratório de Ecologia de Rios e Córregos, Departamento de Ecologia, Instituto de Biologia Roberto Alcantara Gomes - IBRAG, Universidade do Estado do Rio de Janeiro - UERJ, Rua São Francisco Xavier, 524, Maracanã, CEP 20550-013, Rio de Janeiro, RJ, Brazil

${ }^{2}$ Department of Animal Science, Institute of Agricultural and Natural Resources, University of Nebraska Lincoln - UNL, 3310 Holdrege Street, 68583-0974, Lincoln, NE, USA *e-mail: leokleba@gmail.com
\end{abstract}

Cite as: Lisboa, L.K., Thomas, S. and Moulton, T.P. Reviewing carbon spiraling approach to understand organic matter movement and transformation in lotic ecosystems. Acta Limnologica Brasiliensia, 2016, vol. 28, e14.

Abstract: Aim: Understanding riverine carbon cycling is a major issue for stream ecologists. Over the past 60 years, important advance in carbon dynamics and ecosystem energy flow have been made mainly through the Budget and Metabolism approaches. However, much less focus has been given to the quantification of longitudinal movement of organic matter. The concept "Organic Carbon Spiraling" $\left(\mathrm{S}_{\mathrm{OC}}\right)$ was formulated in the early 80 s, and represented a substantial advance in the understanding of the longitudinal flow of elements in lotic systems. Methods: In this review, we summarize the history behind the $S_{\mathrm{OC}}$ concept, cover the major advances at the time of its creation, describe the operational variables and the equation for $S_{O C}$ calculation, and discuss future directions and current applications of this approach. Results/Conclusions: We emphasize the need for integrating the $\mathrm{C}$ spiraling approach in other regions of the globe, given that measurements are almost exclusive of North America. Such comparative studies can elucidate important drivers of $\mathrm{C}$ export, storage and oxidation. Advance in dissolved organic carbon characterization, and improvements in heterotrophic respiration measurements are required to improve $S_{\mathrm{OC}}$ accuracy, as well as realistic estimates of benthic stock. With the current interest in examining how lotic systems contribute to regional and global C budgets, we argue that $S_{\mathrm{OC}}$ is an effective way to achieve this goal and answer classical questions in stream ecology.

Keywords: carbon turnover; spiraling length; stream; energy flow; longitudinal transport; ecosystem function.

Resumo: Objetivo: Compreender o ciclo fluvial do carbono é uma questão essencial para ecólogos de riachos. Nos últimos 60 anos, avanços importantes na dinâmica do carbono e fluxo de energia do ecossistema foram feitos principalmente através das abordagens de Budget e Metabolismo. Apesar disso, pouco foco tem sido dado à quantificação do movimento longitudinal da matéria orgânica. O conceito "Espiral do Carbono Orgânico" $\left(S_{O C}\right)$ foi formulado no início dos anos 80, e representou um avanço substancial no entendimento do fluxo longitudinal dos elementos em ecossistemas lóticos. Métodos: Nessa revisão, nós resumimos a história por trás do conceito de $S_{\mathrm{OC}}$, cobrimos os principais avanços na época de sua criação, descrevemos as variáveis operacionais e a equação para o cálculo de $\mathrm{S}_{\mathrm{OC}}$, e discutimos direçôes futuras e aplicaçóes atuais dessa abordagem. Resultados/Conclusóes: Nós 
enfatizamos a necessidade de integrar a abordagem de espiral de $\mathrm{C}$ em outras regióes do globo, dado que medidas de $S_{\mathrm{OC}}$ são quase que exclusivas da América do Norte. Tais estudos comparativos poderiam elucidar importantes variáveis controladoras da exportaçáo, estocagem e oxidação do carbono fluvial. Avanços na caracterização do carbono orgânico dissolvido, e melhorias nas medidas de respiração heterotrófica são necessários para aumentar a acurácia nos cálculos de $\mathrm{S}_{\mathrm{OC}}$, assim como estimativas realistas de estoque bêntico. Com o recente interesse em examinar como sistemas lóticos contribuem para o balanço regional e global de $\mathrm{C}$, nós argumentamos que a abordagem de espiral é uma maneira efetiva de atingir esses objetivos e auxiliar a responder questóes clássicas da ecologia de riachos.

Palavras-chave: turnover de carbono; comprimento de espiral; riacho; fluxo de energia; transporte longitudinal; funcionamento de ecossistemas.

\section{Introduction}

The school of G. E. Hutchinson was responsible for the development of ecosystem metabolism and ecosystem biogeochemistry in the 1940s and 1950s (Fisher et al., 2004), publishing classical papers about energy cycling and trophic succession in aquatic ecosystems (Lindeman, 1942). Stream metabolism grew specifically from Howard T. Odum, a student of Hutchinson who advanced stream and ecosystem ecology with pioneering studies in Florida, where he used an oxygen mass-balance approach to quantify primary production and community respiration and characterize energy flow and trophic structure of Silver Springs (Odum, 1956, 1957). Those energy budget approaches started an era of holistic studies in stream ecology, grounded in carbon dynamics and ecosystem energy flow (Minshall et al., 1985; Fisher et al., 2004).

Stream ecologists incorporated and extended these early studies through experiments assessing the importance of allochthonous input (Minshall, 1967; Kaushik \& Hynes, 1971; Cummins et al., 1973), elucidating patterns in trophic web (Cummins, 1973) and discoursing about heterotrophy (Cummins, 1974) or autotrophy (Minshall, 1978) of these systems. After the development of the "small-watershed ecosystem" concept by Bormann \& Likens (1968) at Hubbard Brook, Fisher \& Likens (1972, 1973) quantified the annual budget of the Bear Brook stream, in which they measured all input and output energy flows in the form of organic matter $(\mathrm{OM})$. From these fluxes, the authors initiated research in total OM budget, promulgating the view of streams being open ecosystems strongly connected with the watershed.

The complexity and diversity of lotic ecosystems complicate the creation of unifying concepts and theories about them (Minshall et al., 1983). However, progress has been made starting with early ideas addressing longitudinal succession and community structure by Odum (1956) and Margalef (1960). The unidirectional flow of water longitudinally connects streams and rivers through the transport of dissolved and particulate material. This means that much of the nutrient and food resources available at a specific location are delivered from upstream sources and modified by the functioning of the stream above it (Webster \& Patten, 1979). Considering the spatial aspect (transversal and longitudinal) of material movement, and the use by downstream organisms, the term "spiraling" was proposed first by Webster (1975, apud Webster \& Patten, 1979), and after by Wallace et al. (1977), referring to both transport and cycling process in streams. Along with the River Continuum Concept (Vannote et al., 1980), spiraling concept represented a shift away from the segment approach toward a view of the stream as a longitudinally distributed, transporting system (Newbold et al., 1982b).

Even though the "spiraling" concept was first proposed for carbon fluxes downstream (Webster, 1975 apud Webster \& Patten, 1979), and later amplified to include biogeochemical cycling of nutrients between the organic and inorganic form (Newbold et al., 1981; Elwood et al., 1983), the first reference of "organic carbon spiraling" was published only in 1982 by Newbold et al., who adapted the concept to organic carbon processing in streams. In the paper, the authors develop the concept of organic carbon "turnover length" $\left(\mathrm{S}_{\mathrm{OC}}\right)$ and derive expressions for calculating comparing this new index with two others previously proposed in the literature.

"Carbon turnover length" is defined as the average or expected downstream distance travelled by organic carbon molecules during its residence in the stream in a fixed or reduced form (Newbold et al. 1982a). Basically, it is the distance travelled by a carbon atom between its entry or fixation in the stream and its ultimate oxidation via respiration. Thus, $S_{O C}$ values are a function of the rate at which the organic carbon pool moves downstream $\left(\mathrm{V}_{\mathrm{OC}}\right)$ 
and the rate of its oxidation via respiration $\left(\mathrm{K}_{\mathrm{OC}}\right)$ (Equation 1):

$$
\mathrm{S}_{\mathrm{OC}}=\frac{\mathrm{V}_{\mathrm{OC}}}{\mathrm{K}_{\mathrm{OC}}}
$$

Before Newbold's paper there were other terms referring to organic carbon processing in lotic ecosystems, like "ecosystem efficiency" (EE) and "stream metabolism index" (SMI) (Newbold et al., 1982a). EE was defined by Fisher \& Likens (1973) as the ratio between the energy utilized and the total energy input to the system $=\mathbf{C R} / \mathbf{I}$. The ratio derived from the P/R diagram created by Odum (1956) to evaluate autotrophy or heterotrophy in ecosystems (Rosenfeld \& Mackay, 1987) observed later that the transition between autotrophy and heterotrophy in streams is not properly expressed by the $\mathrm{P} / \mathrm{R}$ ratio because it does not shows the extent of production that comes from instream primary producers, and the extent that comes from external input). The EE index allowed the assessment whether a stream was accumulating or losing organic carbon. However, it showed some limitations that hamper comparing different open ecosystems (Fisher, 1977) because it did not measured the degree to which respiration rates were in balance with inputs (Newbold et al., 1982a).

This concept was improved later when Fisher (1977) developed the SMI index, as a loading factor that indicates the rate of increase or decrease of total organic matter concentration per unit ecosystem. SMI was defined as simply the ratio of observed respiration to respiration required for zero loading in the system, which can be used to compare total processing efficiencies in streams of any size (Fisher, 1977). Newbold et al. (1982a) suggested that organic carbon turnover length and SMI are complementary, and proposed an Equation 2 relating the two indices:

$$
\operatorname{SMI}(\mathrm{x})=1-\exp \left(\frac{-\mathrm{x}}{\operatorname{Soc}}\right)
$$

where " $\mathrm{x}$ " is the distance $(\mathrm{m})$ from headwaters to the studied reach. Both indices use similar properties of a stream, but the difference relies on the fact that $\mathrm{EE}$ and SMI are reach length dependent, while $S_{\text {OC }}$ can be calculated (at least theoretically) for any given point of the stream (Newbold et al., 1982a). While SMI measures the processing of organic carbon from lateral input, $\mathrm{S}_{\mathrm{OC}}$ calculates the relative processing of all the carbon that is within the ecosystem considering upstream input.
The present paper focuses on organic carbon spiraling considering that this approach represents a substantial advance in the problem of longitudinal flow of elements in lotic systems (Fisher et al., 2004; Webster, 2007). Many studies have been done within the physical description of biological process and experimentation with inorganic nutrients, but little progress was made on the quantification of organic matter longitudinal movement (Minshall et al., 2000). Still, as attested Fisher et al. (2004), despite of the calculation of spiraling length being intensively laborious, it gets to the essence of stream biogeochemistry and solves some present gaps in the "total budget" approaches. The current discussions about carbon cycling, exportation and emissions in lotic ecosystem can be improved with well-grounded concepts of stream ecology, and this review aims to enlighten the $\mathrm{C}$ spiraling approach in this perspective. Nevertheless, one of the goals of this paper is to be a good aggregate of data and detailed information about the parameters required for $S_{\mathrm{OC}}$ calculation. We searched papers with the topics "carbon spiraling" + "stream" and "carbon turnover" + "stream" in title, abstract and key-words in Web of Science and Scopus bases during 2015.

\section{Organic Carbon Components}

Organic carbon (OC) pool is not homogenous, and specific pools are likely to travel and transform at different rates. Measurements of different components of OC are necessary for estimates of $\mathrm{C}$ turnover rates and spiraling length. These components are summarized as autochthonous and allochthonous particles of carbon transported downstream, and those that are stocked in the riverbed.

The water column of streams transports both particulate and dissolved forms of OC (POC and DOC, respectively). This mobile $\mathrm{C}$ is defined as the transported organic carbon (TOC). Authors have classified $\mathrm{C}$ particles in a variety of size ranges, but basically all of them categorize POC classes into coarse particulate organic carbon (CPOC: $x>1 \mathrm{~mm}$ or $x>0.25 \mathrm{~mm}$ ) and fine particulate organic carbon (FPOC: $1 \mathrm{~mm}>\mathrm{x}>0.45 \mu \mathrm{m}$ ) (Young \& Huryn, 1997; Wallace et al., 2006). FPOC can further be subdivided into the categories of medium-large (1 mm-250 $\mu \mathrm{m})$, small $(250-100 \mu \mathrm{m})$, fine (100-45 $\mu \mathrm{m}$ ), very fine (VFPOC: $25-45 \mu \mathrm{m}$, 15-52 $\mu \mathrm{m}$ or $30-60 \mu \mathrm{m}$ ) and ultrafine (UPOC: 52-0.45 $\mu \mathrm{m}$ or $25-0.45 \mu \mathrm{m}$ ) (Young \& Huryn, 1997; Newbold et al., 2005; Thomas et al., 2005; Wallace et al., 2006). Particles smaller than $0.45 \mu \mathrm{m}$ 
are considered to be DOC (Thomas et al., 2005). These components represent all organic carbon present in the water column that is transported downstream. Suspended particulate forms are also known as seston or sestonic carbon, which includes plankton and organic detritus.

TOC originates from internal sources (mainly periphyton and detritus) or external sources (terrestrial vegetation, soil, atmosphere) (Wallace et al., 1982), and its concentration depends on the biota (Wallace et al., 1991) physical abrasion and channel retention (Bilby, 1981; Wallace et al., 1995). The particulate fraction is composed primarily of unidentifiable detritus and fragments of vascular plant and algae (Webster et al., 1995). Studies have shown that most of the TOC in streams is composed of the smallest fractions of organic C, as ultrafine (Minshall et al., 1983; Young \& Huryn, 1997; Thomas et al., 2005) or even dissolved organic carbon (Mulholland, 1981; Griffiths et al., 2012). The balance of transport and metabolic processing results in the accumulation of fine particles downstream (Young \& Huryn, 1997), and mean particle size typically gets smaller with increasing river order (Minshall et al., 1983). The amount of coarse particulate OC (CPOC) is usually at least one order of magnitude lower than FPOC (Minshall et al., 1992) and becomes almost negligible for the calculation of total TOC base flow of small streams. According Webster et al. (1995), the ecosystem may lose sestonic POC through three mechanisms: microbial decomposition, filter-feeder removal and deposition.

The dissolved fraction can be transformed into $\mathrm{CO}_{2}$ either by microbial oxidation or photolysis (Battin et al., 2008). Usually the largest amount of carbon in TOC is represented by the dissolved organic C, that can vary from 1,97 to $41,8 \mathrm{mg} \mathrm{C.L} \mathrm{L}^{-1}$ (Meyer \& Edwards, 1990; Griffiths et al., 2012). The major classes of organic carbon in river water are fluvic acid, humic acid, hydrophilic acids, carbohydrates, carboxylic acids and amino acids (Kaplan \& Newbold, 2003). As for its lability, DOC can be separated in humic substances as more susceptible to oxidation, and monomers (mainly carboxylic acids) as more refractory (Kaplan \& Newbold, 2003).

The fraction of carbon that is deposited in riverbeds becomes part of the benthic stock of organic matter (BOM), or benthic organic carbon (BOC). According one of the Ten Laws of Ecosystem Theory, "mass, including biomass, and energy are conserved" (Jorgensen, 2009). In this perspective of energy conservation, BOC can be understood as the net results of input and output process: $\mathbf{B}=\mathbf{I}-\mathbf{O}$. Input includes allochthonous input, primary production, consumers egestion and deposition of OC transported from upstream. Output includes consumption, microbial decomposition, leaching of matter and downstream transport (Webster et al., 1995).

The benthic stock has been measured in a variety of size classes, but most researches classify it only into coarse benthic organic matter (CBOM: $\mathrm{x}>1 \mathrm{~mm}$ ) and fine benthic organic matter (FBOM: $1 \mathrm{~mm}-0.45 \mu \mathrm{m}$ ). Some authors classified yet a third category of ultrafine benthic matter (UBOM: 52-0.45 $\mu \mathrm{m}$ ) (Minshall et al., 1983; Thomas et al., 2005). Measurements of BOM in streams are complicated due to the patchy distribution and deep storage (Webster \& Meyer, 1997), and are often underestimated by the lack of measures of FBOM (Wallace et al., 2006). Moreover, standing crop could show large variation between erosive (riffles) and depositional (pools) stretches (Wallace et al., 2006). However, BOC is essential in calculating spiraling lengths and can strongly influence the final result. Without realistic estimates of the benthic storage all calculation may be compromised.

The composition of particle size classes of benthic stock can vary largely among streams according characteristics of deposition, retention, processing and transport peculiar to each system. Studies have shown that more than half of the BOC is made up of the smallest carbon fractions, like FBOC (Griffiths et al., 2012) or UBOC (Minshall et al., 1983; Thomas et al., 2005). However, as the processing rates of wood debris are quite slow, benthic storage of woody material may be much higher than leaves (Jones Junior, 1997), and large logs deposited in streams can remain years in the same place with low evidence of mass decay (Webster et al., 1999). Due to high allochthonous inputs and efficient retention, headwaters tend to have the BOC composed of coarser particles (Newbold et al., 1982a), which decreases in size downstream by physical, chemical and biological process (Minshall et al., 1983; Webster et al., 1999). Nevertheless, as made explicit by Minshall et al. (1983), local geomorphic factors are more important for explaining variance of detritus standing crop than either stream size (order) or season. 


\section{Metabolism}

Primary productivity is defined as the formation rate of OM from inorganic carbon. Photoautotrophy via photosynthesis is the most common form of autotrophy in most ecosystems, though chemoautotrophy (e.g. nitrification) can be locally important (Strauss et al., 2002). Some of this total fixed carbon (gross primary production; GPP) is lost via autotrophic respiration $\left(\mathrm{R}_{\mathrm{a}}\right)$, the remaining builds biomass and is referred to as net primary productivity (NPP) (Bott, 2006). The processes of production and respiration in streams directly influence dissolved oxygen (DO) and $\mathrm{CO}_{2}$ concentrations in water, and their production and consumption combine to quantify the metabolism of a stream (Odum, 1956). Respiration measures include heterotrophic respiration $\left(R_{h}\right)$ and $R_{a}$, and therefore are also called community respiration (CR). The main primary producers are algae in periphyton, bryophytes, macrophytes and cyanobacteria (Bott, 2006). Considering respiration, that of heterotrophic microbiota greatly exceeds algae consumption (despite periphytic algae respiration being very significant in unshaded streams), and fauna contribute the smallest portion of CR (Webster et al., 1995).

Stream metabolism is measured generally from daily curves of OD change, although primary productivity can also be measured through chlorophyll of periphyton (Morin et al., 1999; Moulton et al., 2015). Based on the premise that changes in OD are related to photosynthesis, respiration, and gas exchange with atmosphere, productivity can be directly calculated from the net oxygen change in light (balance of GPP and CR) and respiration in the dark (Bott, 2006). Dissolved $\mathrm{O}_{2}$ change can be measured in enclosed chambers with the relevant substrate and stream water (Bott et al., 1978), or by the "open-channel" method directly in the stream (Odum, 1956). Specifically, CR can be computed in a simple way by the formula (Equation 3):

$$
\mathrm{CR}(\mathrm{mgO} 2 \mathrm{~L}-1 \text { dia }-1)=\frac{\sum_{06: 00}^{18: 00} \mathrm{ROC}+\left(\mathrm{D}^{*} \mathrm{k}\right)}{\Delta \mathrm{t}}
$$

where $R O C$ is the change rate of $\mathrm{O}_{2}$ per hour, $D$ is $\mathrm{O}_{2}$ deficit and $k$ is the reaeration coefficient, divided by time interval (to return a rate per time). For $S_{\mathrm{OC}}$ calculations, respiration rates must be transformed firstly in $\mathrm{g} \mathrm{O}_{2} \mathrm{~m}^{-2}$ day ${ }^{-1}$ (dividing by depth), then converted to unities of carbon using a respiratory coefficient (RQ) of 0,85, according Bott (2006) (Equation 4):

$$
\mathrm{gC}=\mathrm{gO} 2 * \mathrm{RQ} * \frac{12}{32}
$$

where 12 is the atomic weight of carbon, and 32 the atomic weight of oxygen. Finally, as $S_{\mathrm{OC}}$ requires only heterotrophic respiration, the $\mathrm{CR}$ is converted in $R_{h}$ using a coefficient of $p=0.38$, with the formula (Thomas et al., 2005) (Equation 5):

$$
\mathrm{R}_{\text {het }}=\mathrm{CR}-\rho \mathrm{GPP}
$$

A difficulty in the open-channel method is that the rate of "reaeration" needs to be estimated adjusting the changes caused by metabolism. The problem is most critical in turbulent streams with low productivity. The rate of reaeration is a function of the slope, deep, water velocity, channel irregularity and the difference between the observed oxygen concentration in the water and the concentration at $100 \%$ saturation - i.e. O2 deficit (Young \& Huryn, 1999). Measures of reaeration are calculated from empirical equations (based on flow, slope and deep), inert gas injection in the water as a tracer, or from changes in oxygen concentration during the dark (Young \& Huryn, 1999; Bott, 2006)

From metabolism, authors summarize the calculus of ecosystem efficiency to indicates whether a stream is a net producer or consumer of OM, simply by the ratio of primary production and community respiration: GPP/CR or simply $\mathrm{P} / \mathrm{R}$. Primary determinants of metabolism rates in stream are incident light and a variety of site-specific factors controlling the channel morphology (such as "canyon shading", turbidity, organic matter retention, width and depth) (Young \& Huryn, 1999), and on a larger scale, the discharge, nutrients and system temperature (McIntire \& Phinney, 1965; Young \& Huryn, 1996). The rates of GPP, $\mathrm{CR}$ and $\mathrm{P} / \mathrm{R}$ tend to increase downstream along with the increasing scale of the ecosystem and higher insolation rates (Minshall et al., 1983; Bott et al., 1985; Naiman et al., 1987), although some systems do not show relative increase in GPP nor $\mathrm{P} / \mathrm{R}$ ratio downstream (Meyer \& Edwards, 1990; Young \& Huryn, 1996), and falls under the continuum that presents unshaded headwaters (Minshall et al., 1985). It is known that increasing river width increases the incidence of photosynthetic active radiation (PAR) in the water, which is the main determinant of GPP and NPP in streams (Mulholand et al., 2001). 
A good way to represent the stream metabolism considering organic matter fluxes and concentrations is from the organic carbon turnover perspective. As explained Young \& Huryn (1999), relation between stream metabolism and its community, the transport of $\mathrm{OM}$ and land uses are probably more useful when expressed as carbon spiraling length.

\section{Carbon Turnover and Spiraling}

The expressions $C$ spiraling and $C$ turnover are used as synonymous, apart from the condition that spiraling only makes sense in terms of length $(\mathrm{km}, \mathrm{m})$, and turnover can be used both as a rate (day ${ }^{-1}$, representing $\mathrm{K}_{\mathrm{OC}}$ ), as length $(\mathrm{km}$, m; representing $S_{\mathrm{OC}}$ ) of carbon oxidation. Authors have been using mainly the expression $\mathrm{C}$ turnover length (Meyer \& Edwards, 1990; Minshall et al., 1992; Thomas et al., 2005), representing the efficiency of the system in processing organic carbon (Meyer \& Edwards, 1990).

As seen above (Equation 1), calculation of $\mathrm{C}$ turnover length is a function of the carbon fluxes and its oxidation rates, factors directly determined by organic carbon components and system metabolism. After the conceptualization and initial proposition of the formula by Newbold et al. (1982a), spiral length estimates were applied by several authors, with the summarization of $S_{\mathrm{OC}}$ calculation (Thomas et al., 2005) according the Equations 6, 7, 8 and 9:

$$
\begin{aligned}
& \mathrm{V}_{\mathrm{OC}}=\frac{\mathrm{TOC}^{*} \mathrm{Q}}{\mathrm{BOC}^{*} \mathrm{w}} \\
& \mathrm{K}_{\mathrm{OC}}=\frac{\mathrm{R}_{\text {het }}}{\mathrm{BOC}+\left(\mathrm{TOC}^{*} \mathrm{z}\right)} \\
& \mathrm{S}_{\mathrm{OC}}=\frac{\mathrm{V}_{\mathrm{OC}}}{\mathrm{K}_{\mathrm{OC}}} \\
& \mathrm{IR}=\frac{\mathrm{V}_{\mathrm{wat}}}{\mathrm{V}_{\mathrm{OC}}}
\end{aligned}
$$

where $\mathrm{V}_{\mathrm{OC}}$ is the longitudinal velocity of organic carbon $\left(\mathrm{m} \mathrm{day}^{-1}\right)$, TOC $=$ total concentration of transported organic carbon $\left(\mathrm{g} \mathrm{m}^{-3}\right), \mathrm{Q}=$ discharge $\left(\mathrm{m}^{3}\right.$ day $\left.^{-1}\right), \mathrm{BOC}=$ total organic carbon benthic standing stock $\left(\mathrm{g} \mathrm{m}^{-2}\right), \mathrm{w}=$ mean stream width $(\mathrm{m})$, $\mathrm{K}_{\mathrm{OC}}=$ biotic turnover rate of organic carbon $\left(\right.$ day $\left.^{-1}\right)$, $\mathrm{R}_{\text {het }}=$ heterotrophic respiration rate, $\mathrm{z}=$ mean stream deep $(\mathrm{m}), \mathrm{S}_{\mathrm{OC}}=$ organic carbon turnover length $(\mathrm{m}), \mathrm{IR}=$ retention index, and $\mathrm{v}_{\text {wat }}=$ mean water velocity (Thomas et al., 2005).

Carbon spiraling lengths may show large variation between streams and within the own ecosystem. However, the majority of the authors evidence a strong relation with hydrological factors, where SOC increases along with the discharge of the river (Minshall et al., 1983; Meyer \& Edwards, 1990; Minshall et al., 1992; Young \& Huryn, 1997, 1999; Thomas et al., 2005; Webster, 2007; Griffiths et al., 2012). Still, $S_{\mathrm{OC}}$ is affected by temporal patterns (Thomas et al., 2005), land use (Young \& Huryn, 1999; Griffiths et al., 2012), and distance from the headwaters (Newbold et al., 1982a; Webster, 2007), lately because these factors actuate directly in the basic parameters of $\mathrm{S}_{\mathrm{OC}}$ calculation, determining $\mathrm{C}$ component concentrations and metabolic rates. Thus, all the factors that changes concentrations of DOC, sestonic POC, BOC storage, CR and GPP rates, in addition to hydrological factors, influences directly the outcome of the organic carbon turnover lengths in streams.

In headwaters and small ecosystem orders, because of the smaller discharge, higher retentiveness and higher processing rates (Newbold et al., 1982a), a carbon molecule does not need to travel long distance downstream to its oxidation. Griffiths et al. (2012) analyzed six $3^{\text {rd }}$ order streams in Indiana, USA, and found a $S_{\mathrm{OC}}$ ranging from $0.2 \mathrm{~km}$ to $54.4 \mathrm{~km}$, with an average of only $15 \mathrm{~km}$ to the oxidation of an organic carbon molecule fixed in the systems. Other authors found even smaller values in systems ranging from $1^{\text {st }}$ to $6^{\text {th }}$ order (Minshall et al., 1983; Meyer \& Edwards, 1990). With the increasing in orders, the $\mathrm{C}$ spiraling lengths tend to increase, both because the discharge increases, as because the system retentiveness decreases (Newbold et al., 1982a; Meyer \& Edwards, 1990). Analyzing four sites of a $8^{\text {th }}$ order stream, Thomas et al. (2005) found a $S_{\mathrm{OC}}$ ranging from $11 \mathrm{~km}$ to $184 \mathrm{~km}$, with an average of $64 \mathrm{~km}$, distance more than four times higher than the average found in Griffiths et al. (2012).

In spite of this, increases of stream order and ecosystem scale are also positively related to higher $\mathrm{CR}$, and higher respiration rates decreases the relative $S_{\text {OC }}$ length. According to Webster (2007), turnover length increases downstream from headwaters, peaking at about $S_{O C}=130 \mathrm{~km}$, at a distance of $70 \mathrm{~km}$ from the headwaters. From this point, $\mathrm{C}$ turnover length starts to decreases, mainly influenced by the respiration of autochthonous particles which become increasingly important to C budgets. As pointed out by Meyer \& Edwards (1990), although rivers of bigger orders are less efficient in processing organic $\mathrm{C}$ (higher $\mathrm{S}_{\mathrm{OC}}$ ), they still are responsible for most of the metabolic activity 
of the watershed. Still, Young \& Huryn (1999) found maximum $\mathrm{S}_{\mathrm{OC}}$ values of $408 \mathrm{~km}$ in a $3^{\text {rd }}$ order stream, relating this high length with the increase in discharge in the winter and low metabolic rate.

\section{Perspectives}

Despite the relative progress to stream biogeochemistry that the $\mathrm{C}$ spiraling approach has represented (Fisher et al., 2004), its practical use (Young \& Huryn, 1999) and the fact that this concept was made still in the early 1980 s (Newbold et al., 1982a), published data of C turnover length are almost exclusive of USA, with few studies in other countries such as New Zeeland (Young \& Huryn, 1997, 1999), Germany (Proft, 1998) and Canada (Naiman et al., 1987). The lack of studies using this approach in the tropics is a large gap, seen that tropical streams may have different functionality (Dudgeon, 2008), regarding that they can show higher labile organic matter concentrations dissolved in the water - such as amino acid -when compared to temperate streams (Jaffé et al., 2012). Still, it is clear that temporal patterns in the tropics show no restrictions for low temperatures and have strong influence of heavy floods in rainy periods, which certainly changes the basic parameters for the calculation of $\mathrm{S}_{\mathrm{OC}}$.

Perspectives in $\mathrm{C}$ spiraling presupposes new studies about the qualitative differentiation of the organic carbon components seen their different metabolic rates (Fisher et al., 2004), experimentation of specific oxidation of the smallest fractions of $\mathrm{C}$ (Richardson et al., 2013) and improvement of approaches to calculate the resuspension of fine particles in the system (Newbold et al., 2005). Furthermore, as DOC represents the largest organic matter pool in freshwater systems (Wetzel, 1992), and assuming that this component is the most important intermediate in global carbon cycling (Battin et al., 2008), more detailed analyses of its molecular structure and chemical composition could provide critical information for carbon dynamics on a global scale (Jaffé et al., 2012). Improvements of analytical methods to identify whole classes of compounds such as amino acids, peptides, proteins and carbohydrate-like compounds are being made combining chromatography techniques with highly sensitive detectors that can approach the nanomolar range (Kaplan \& Newbold, 2003). Characterization of DOC should also consider recent technics of mass spectrometry in organic molecules such as electrospray and atmospheric pressure photoionization (Hockaday et al.,
2009), compounds could be determined by gas chromatography-mass spectrometer (Jaffé et al., 2012) and biodegradable DOC measured with bioreactors (McLaughlin \& Kaplan, 2013).

In addition, more precise measurements of heterotrophically respired $\mathrm{C}$ are needed to allow more accurate calculations of $\mathrm{C}$ spiraling length (Hall Junior \& Beaulieu, 2013), and good estimations of both groundwater metabolism and reaeration are essential to this achievement. Advancements on the utilization of "tracers" to calculate reaeration in the open-channel method are making use of sulfur hexafluoride (SF6) or argon (Ar). Argon is seen to have advantages in the way that this gas is physically indistinguishable from oxygen, is very cheap, it solves problems of propane (explosion) or SF6 (is not a greenhouse gas), and can be easily measured in a membrane inlet mass spec (Hall, 2015).

The view that riverine systems export much more organic matter then they receive (Naiman et al., 1987; Webster \& Meyer, 1997; Webster et al., 1999) is no longer consistent with carbon fluxes estimates (Jaffé et al., 2012). Instead, inland aquatic systems represent places of active transformation transporting to oceans less than half of the received terrestrial carbon (Cole et al., 2007), and are responsible for a large amount of carbon dioxide outgassing to the atmosphere (Battin et al., 2008). In this perspective, we assume that the carbon spiraling approach is a good way to calculate the specific C dynamics of different lotic systems, firstly because it demands the detailed admeasurement of the main components driving $\mathrm{C}$ cycling, and combine them into an ecological sense of view. As affirmed Hall et al. (2016), metabolism and C spiraling are a good way to examine biogeochemical mechanisms controlling riverine $\mathrm{C}$ cycling. Lastly, we suggest that this approach could be utilized to understand rivers $\mathrm{C}$ dynamics in a broader global scale, and can help to answer classical questions of river ecologists as: "What happens to allochthonous material that falls into streams?" (Webster et al., 1999, p. 687), and: "How can organic carbon be oxidized during its route from continents to oceans given transit times in fluvial ecosystems of days to weeks relative to extended residence times in soils?" (Battin et al., 2008, p. 95).

\section{References}

BATTIN, T.J., KAPLAN, L.A., FINDLAY, S., HOPKINSON, C.S., MARTI, E., PACKMAN, A.I., NEWBOLD, J.D. and SABATER, F. Biophysical 
controls on organic carbon fluxes in fluvial networks. Nature Geoscience, 2008, 1(2), 95-100. http://dx.doi. org/10.1038/ngeo101.

BILBY, R.E. Role of organic debris dams in regulating the export of dissolved and particulate matter from a forested watershed. Ecology, 1981, 62(5), 1234-1243. http://dx.doi.org/10.2307/1937288.

BORMANN, F.H. and LIKENS, G.E. Nutrient cycling. Science, 1968, 155(3761), 424-429. http://dx.doi.org/10.1126/science.155.3761.424. PMid:17737551.

BOTT, T.L. Primary productivity and community respiration. In F.R. HAUER and G.A. LAMBERTI, eds. Methods in stream ecology. 2nd ed. San Diego: Elsevier, 2006, pp. 663-690.

BOTT, T.L., BROCK, J.T., CUSHING, C.E., GREGORY, S.V., KING, D. and PETERSEN, R.C. A comparison of methods for measuring primary productivity and community respiration in streams. Hydrobiologia, 1978, 60(1), 3-12. http://dx.doi. org/10.1007/BF00018681.

BOTT, T.L., BROCK, J.T., DUNN, C.S., NAIMAN, R.J., OVINK, R.W. and PETERSEN, R.C. Benthic community metabolism in four temperate stream systems: an inter-biome comparison and evaluation of the river continuum concept. Hydrobiologia, 1985, 123(1), 3-45. http://dx.doi.org/10.1007/ BF00006613.

COLE, J.J., PRAIRIE, Y.T., CARACO, N.F., MCDOWELL, W.H., TRANVIK, L.J., STRIEGL, R.G., DUARTE, C.M., DOWNING, J.A., MIDDELBURG, J.J. and MELACK, J. Plumbing the global carbon cycle: integrating inland waters into the terrestrial carbon budget. Ecosystems, 2007, 10(1), 171-184. http://dx.doi.org/10.1007/s10021006-9013-8.

CUMMINS, K.W., PETERSEN, R.C., HOWARD, F.O., WUYCHECK, J. and HOLT, V.I. The utilization of leaf litter by stream detritivores. Ecology, 1973, 54(2), 336-345. http://dx.doi. org/10.2307/1934341.

CUMMINS, K.W. Trophic relations of aquatic insects. Annual Review of Entomology, 1973, 18(1), 183-206. http://dx.doi.org/10.1146/annurev. en.18.010173.001151.

CUMMINS, K.W. Structure and function of streams ecosystem. Bioscience, 1974, 24(11), 632-641. http:// dx.doi.org/10.2307/1296676.

DUDGEON, D. Tropical stream ecology. London: Elsevier, 2008, 324 pp.

ELWOOD, J.W., NEWBOLD, J.D., O’NEILL, R.V. and VAN WINKLE, W. Resource spiraling: an operational paradigm for analyzing lotic ecosystems. In T.D. FONTAINE and S.M. BARTELL, eds. Dynamics of lotic ecosystems. Ann Arbor: Ann Arbor Science Publishers M.I., 1983, pp. 3-27.
FISHER, S.G. and LIKENS, G.E. Ecosystem: organic energy budget. Bioscience, 1972, 22(1), 33-35. http:// dx.doi.org/10.2307/1296183.

FISHER, S.G. and LIKENS, G.E. Energy flow in Bear Brook, New Hampshire: an integrative approach to stream ecosystem metabolism. Ecological Monographs, 1973, 43(4), 421-439. http://dx.doi. org/10.2307/1942301.

FISHER, S.G. Organic matter processing by a streamsegment ecosystem: fort river, Massachusetts, USA. Internationale Revue der Gesamten Hydrobiologie, 1977, 62(6), 701-727. http://dx.doi.org/10.1002/ iroh.1977.3510620601.

FISHER, S.G., SPONSELLER, R.A. and HEFERNAN, J.G. Horizons in stream biogeochemistry: flowpaths to progress. Ecology, 2004, 85(9), 2369-2379. http:// dx.doi.org/10.1890/03-0244.

GRIFFITHS, N.A., TANK, J.L., ROYER, T.V., WARRNER, T.J., FRAUENDORF, T.C., ROSIMARSHALL, E.J. and WHILES, M.R. Temporal variation in organic carbon spiraling in Midwestern agricultural streams. Biogeochemistry, 2012, 108(1-3), 149-169. http://dx.doi.org/10.1007/s10533-0119585-z.

HALL JUNIOR, R.O. and BEAULIEU, J.J. Estimating autotrophic respiration in streams using daily metabolism data. Freshwater Science, 2013, 32(2), 507-516. http://dx.doi.org/10.1899/12-147.1.

HALL, R.O. Re: metabolism [personal message via email]. [viewed 25 Aug. 2015].

HALL, R.O., TANK, J.L., BAKER, M.A., ROSIMARSHALL, A.J. and HOTCHKISS, E.R. Metabolism, gas exchange, and carbon spiraling in rivers. Ecosystems, 2016, 19(1), 73-86. http://dx.doi. org/10.1007/s10021-015-9918-1.

HOCKADAY, W.C., PURCELL, J.M., MARSHALL, A.G., BALDOCK, J.A. and HATCHER, P.G. Electrospray and photoionization mass spectrometry for the characterization of organic matter in natural waters: a qualitative assessment. Limnology and Oceanography, Methods, 2009, 7(1), 81-95. http:// dx.doi.org/10.4319/lom.2009.7.81.

JAFFÉ, R., YAMASHITA, Y., MAIE, N., COOPER, W.T., DITTMAR, T., DODDS, W.K., JONES, J.B., MYOSHI, T., ORTIZ-ZAYAS, J.R., PODGORSKI, D.C. and WATANABE, A. Dissolved organic matter in headwater streams: compositional variability across climatic regions of North America. Geochimica et Cosmochimica Acta, 2012, 94, 95-108. http://dx.doi. org/10.1016/j.gca.2012.06.031.

JONES JUNIOR, J.B. Benthic organic matter storage in streams: influence of detrital import and export, retention mechanisms, and climate. Journal of the North American Benthological Society, 1997, 16(1), 109-119. http://dx.doi.org/10.2307/1468243. 
JORGENSEN, S.E. Fundammental laws in ecology. In S.E. JORGENSEN, ed. Ecosystem ecology. Amsterdam: Elsevier, 2009, pp. 33-38.

KAPLAN, L.A. and NEWBOLD, J.D. The role of monomers in stream ecosystem metabolism. In S.E.G. FINDLAY and R.L. SINSABAUGH, eds. Aquatic ecosystems: interactivity of dissolved organic matter. Amsterdam: Elsevier, 2003, pp. 97-119.

KAUSHIK, N.K. and HYNES, H.B.N. Fate of dead leaves that fall into streams. Archiv für Hydrobiologie, 1971, 68, 465-515.

LINDEMAN, R.L. The trophic dynamic aspect of ecology. Ecology, 1942, 23(4), 399-417. http://dx.doi. org/10.2307/1930126.

MARGALEF, R. Ideas for a synthetic approach to the ecology of running waters. Internationale Revue der Gesamten Hydrobiologie, 1960, 45(1), 133-153. http://dx.doi.org/10.1002/iroh.19600450108.

MCINTIRE, C.D. and PHINNEY, H.K. Laboratory studies of periphyton and community metabolism in lotic environments. Ecological Monographs, 1965 , 35(3), 237-258. http://dx.doi.org/10.2307/1942138.

MCLAUGHLIN, C. and KAPLAN, L.A. Biological lability of dissolved organic carbon in stream water and contributing terrestrial sources. Freshwater Science, 2013, 32(4), 1219-1230. http://dx.doi. org/10.1899/12-202.1.

MEYER, J.L. and EDWARDS, R.T. Ecosystem metabolism and turnover of organic carbon along a blackwater River Continuum. Ecology, 1990, 71(2), 668-677. http://dx.doi.org/10.2307/1940321.

MINSHALL, G.W. Role of allochthonous detritus in the trophic structure of a woodland springbrook community. Ecology, 1967, 48(1), 139-149. http:// dx.doi.org/10.2307/1933425.

MINSHALL, G.W. Autotrophy in stream ecosystems. Bioscience, 1978, 28(12), 767-771. http://dx.doi. org/10.2307/1307250.

MINSHALL, G.W., CUMMINS, K.W., PETERSEN, R.C., CUSHING, C.E., BRUNS, D.A., SEDELL, J.R. and VANNOTE, R.L. Developments in stream ecosystem theory. Canadian Journal of Fisheries and Aquatic Sciences, 1985, 42(5), 1045-1055. http:// dx.doi.org/10.1139/f85-130.

MINSHALL, G.W., PETERSEN, R.C., BOTT, T.L., CUSHING, C.E., CUMMINS, K.W., VANNOTE, R.L. and SEDELL, J.R. Stream Ecosystem Dynamics of the Salmon River, Idaho: An 8th-Order System. Journal of the North American Benthological Society, 1992, 11(2), 111-137. http:// dx.doi.org/10.2307/1467380.

MINSHALL, G.W., PETERSEN, R.C., CUMMINS, K.W., BOTT, T.L., SEDELL, J.R., CUSHING, C.E. and VANNOTE, R.L. Interbiome comparison of stream ecosystem dynamics. Ecological
Monographs, 1983, 53(1), 1-25. http://dx.doi. org/10.2307/1942585.

MINSHALL, G.W., THOMAS, S.A., NEWBOLD, J.D., MONAGHAN, M.T. and CUSHING, C.E. Physical factors infl uencing fi ne organic particle transport and deposition in streams. Journal of the North American Benthological Society, 2000, 19(1), 1-16. http://dx.doi.org/10.2307/1468278.

MORIN, A., LAMOUREUX, W. and BUSNARDA, $\mathrm{J}$. Empirical models predicting primary productivity from chlorophyll a and water temperature for stream periphyton and lake and ocean phytoplankton. Journal of the North American Benthological Society, 1999, 18(3), 299-307. http://dx.doi. org/10.2307/1468446.

MOULTON, T.P., LOURENÇO-AMORIN, C., SASADA-SATO, C., NERES-LIMA, V. and ZANDONA, E. Dynamics of algal production and ephemeropteran grazing of periphyton in a tropical stream. International Review of Hydrobiology, 2015, 99, 1-8.

MULHOLAND, P.J., FELLOWS, C.S., TANK, J.L., GRIMM, N.B., WEBSTER, J.R., HAMILTON, S.K., MARTÍ, E., ASHKENAS, L., BOWDEN, W.B., DODDS, W.K., MCDOWELL, W.H., PAUL, M.J. and PETERSON, B.J. Inter-biome comparison of factors controlling stream metabolism. Freshwater Biology, 2001, 46(11), 1503-1517. http:// dx.doi.org/10.1046/j.1365-2427.2001.00773.x.

MULHOLLAND, P.J. Carbon flow in a swamp-stream ecosystem. Ecological Monographs, 1981, 51(3), 307322. http://dx.doi.org/10.2307/2937276.

NAIMAN, R.J., MELILLO, T.M., LOCK, M.A., FORD, T.E. and REICE, S.R. Longitudinal patterns of ecosystem processes and community structure in a subarctic River Continuum. Ecology, 1987, 68(5), 1139-1156. http://dx.doi.org/10.2307/1939199.

NEWBOLD, J.D., ELWOOD, J.W., O’NEILL, R.V. and VAN WINKLE, W. Nutrient spiraling in streams: the concept and its field measurement. Canadian Journal of Fisheries and Aquatic Sciences, 1981, 38, 860-863. http://dx.doi.org/10.1139/ f81-114.

NEWBOLD, J.D., MULHOLLAND, P.J., ELWOOD, J.W. and O'NEILL, R.V. Organic carbon spiraling in stream ecosystems. Oikos, 1982a, 38(3), 266-272. http://dx.doi.org/10.2307/3544663.

NEWBOLD, J.D., O’NEILL, R.V., ELWOOD, J.W. and VAN WINKEL, W. Nutrient spiraling in streams: Implications for nutrient limitation and invertebrate activity. American Naturalist, 1982b, 120(5), 628-652. http://dx.doi.org/10.1086/284017.

NEWBOLD, J.D., THOMAS, S.A., MINSHALL, G.W., CUSHING, C.E. and GEORGIAN, T. Deposition, benthic residence, and resuspension of fine organic particles in a mountain stream. 
Limnology and Oceanography, 2005, 50(5), 15711580. http://dx.doi.org/10.4319/lo.2005.50.5.1571.

ODUM, H.T. Primary production in flowing waters. Limnology and Oceanography, 1956, 1(2), 102-117. http://dx.doi.org/10.4319/lo.1956.1.2.0102.

ODUM, H.T. Trophic structure and productivity of Silver Springs, Florida. Ecological Monographs, 1957, 27(1), 55-112. http://dx.doi.org/10.2307/1948571.

PROFT, G. Carbon turnover by respiration in the river Ilm (Thuringia, Germany). Acta Hydrochimica et Hydrobiologica, 1998, 26(6), 355-361. http://dx.doi.org/10.1002/ (SICI) 1521-401X(199811)26:6<355::AIDAHEH355>3.0.CO;2-1.

RICHARDSON, D.C., NEWBOLD, J.D., AUFDENKAMPE, A.K., TAYLOR, P.G. and KAPLAN, L.A. Measuring heterotrophic respiration rates of suspended particulate organic carbon from stream ecosystems. Limnology and Oceanography, Methods, 2013, 11(5), 247-261. http://dx.doi. org/10.4319/lom.2013.11.247.

ROSENFELD, J.S. and MACKAY, R.J. Accessing the food base of stream ecosystems: alternatives to the P/R ratio. Oikos, 1987, 50(1), 141-147. http:// dx.doi.org/10.2307/3565412.

STRAUSS, E.A., MITCHELL, N.L. and LAMBERTI, G.A. Factors regulating nitrification in aquatic sediments: effects of organic carbon, nitrogen availability, and $\mathrm{pH}$. Canadian Journal of Fisheries and Aquatic Sciences, 2002, 59(3), 554-563. http:// dx.doi.org/10.1139/f02-032.

THOMAS, S.A., ROYER, T.V., SNYDER, E.B. and DAVIS, J.C. Organic carbon spiraling in an Idaho river. Aquatic Sciences, 2005, 67(4), 424-433. http:// dx.doi.org/10.1007/s00027-005-0790-5.

VANNOTE, R.L., MINSHALL, G.W., CUMMINS, K.W., SEDELL, J.R. and CUSHING, C.E. The River Continuum Concept. Canadian Journal of Fisheries and Aquatic Sciences, 1980, 37(1), 130-137. http://dx.doi.org/10.1139/f80-017.

WALLACE, J.B., CUFFNEY, T.F., WEBSTER, J.R., LUGTHART, G.J., CHUNG, K. and GOLDOWITZ, B.S. Export of fine organic particles from headwater streams: effects of season, extreme discharges, and invertebrate manipulation. Limnology and Oceanography, 1991, 36(4), 670-682. http:// dx.doi.org/10.4319/lo.1991.36.4.0670.

WALLACE, J.B., HUTCHENS, J.J. and GRUBAUGH, J.W. (2006). Transport and storage of FPOM. In F.R. HAUER and G.A. LAMBERTI, eds. Methods in stream ecology. 2nd ed. San Diego: Elsevier, 2006, pp. 249-271.

WALLACE, J.B., ROSS, D.H. and MEYER, J.L. Seston and dissolved organic carbon dynamics in a southern Appalachian stream. Ecology, 1982, 63(3), 824-838. http://dx.doi.org/10.2307/1936802.
WALLACE, J.B., WEBSTER, J.R. and MEYER, J.L. Influence of $\log$ additions on physical and biotic characteristics of a mountains stream. Canadian Journal of Fisheries and Aquatic Sciences, 1995, 52(10), 2120-2137. http://dx.doi.org/10.1139/f95-805.

WALLACE, J.B., WEBSTER, J.R. and WOODALL, W.R. The role of filter feeders in flowing waters. Archiv für Hydrobiologie, 1977, 79, 506-532.

WEBSTER, J.R. and MEYER, J.L. Organic matter budgets for streams: a synthesis. Journal of the North American Benthological Society, 1997, 16(1), 141-161. http://dx.doi.org/10.2307/1468247.

WEBSTER, J.R. and PATTEN, B.C. Effects of watershed perturbation on stream potassium and calcium dynamics. Ecological Monographs, 1979, 49(1), 51-72. http://dx.doi.org/10.2307/1942572.

WEBSTER, J.R. Spiraling down the river continuum: stream ecology and the U-shaped curve. Journal of the North American Benthological Society, 2007, 26(3), 375-389. http://dx.doi.org/10.1899/06-095.1.

WEBSTER, J.R., BENFIELD, E.F., EHRMAN, T.P., SCHAEFFER, M.A., TANK, J.L., HUTCHENS, J.J. and D'ANGELO, D.J. What happens to allochthonous material that falls into streams? A synthesis of new and published information from Coweeta. Freshwater Biology, 1999, 41(4), 687-705. http://dx.doi.org/10.1046/j.13652427.1999.00409.x.

WEBSTER, J.R., WALLACE, J.B. and BENFIELD, E.F. Organic process in streams of the eastern United States. In C.E. CUSHING, K.W. CUMMINS and G.W. MINSHALL, eds. River and stream ecosystems. Amsterdam: Elsevier Science, 1995, pp. 117-187.

WETZEL, R.G. Gradient-dominated ecosystems: sources and regulatory functions of dissolved organic matter in freshwater ecosystems. Hydrobiologia, 1992, 229(1), 181-198. http://dx.doi.org/10.1007/ BF00007000.

YOUNG, R.G. and HURYN, A.D. Interannual variation in discharge controls ecosystem metabolism along a grassland river continuum. Canadian Journal of Fisheries and Aquatic Sciences, 1996, 53(10), 21992211. http://dx.doi.org/10.1139/f96-186.

YOUNG, R.G. and HURYN, A.D. Longitudinal patterns of organic matter transport and turnover along a New Zeland grassland river. Freshwater Biology, 1997, 38(1), 93-107. http://dx.doi. org/10.1046/j.1365-2427.1997.00196.x.

YOUNG, R.G. and HURYN, A.D. Effects of land use on stream metabolism and organic matter turnover. EcologicalApplications, 1999, 9(4), 1359-1376. http:// dx.doi.org/10.1890/1051-0761(1999)009[1359:EO LUOS]2.0.CO;2. 